\title{
The Effects Of The U.S. Price Control Policies On OPEC: Lessons From The Past
}

\author{
Khalid M. Kisswani, Ph.D., Gulf University for Science \&Technology, Kuwait
}

\begin{abstract}
In 1973-1974, the U.S. faced the so-called "Energy Crisis" due to the Arab oil embargo and a quadrupling of world crude oil prices by OPEC. This led the U.S. to use a" Price Control" policy in the domestic energy market. The effects of such policy are explored and well documented. However, the responses of OPEC producers to such a policy need further attention. This paper examines the effects of these price controls on OPEC's extraction path and the relation between the harm function and the change in OPEC production. The results show some evidence that OPEC did respond differently to price controls applied by the U.S. For some periods it cut production, while in other periods production levels increased. The results also show some evidence regarding Wirl (2008) that OPEC includes political support as part of its objective function when it comes to oil extraction.
\end{abstract}

Keywords: OPEC; Price Controls; Energy Economics; US Energy Crisis

\section{INTRODUCTION}

asoline is one of the major fuels consumed in the U.S. and the main product refined from crude oil. Over the last 20 years, changes in crude oil prices have explained 85 percent of the changes in the price of gasoline in the U.S. This indicates that the world price of crude oil is the primary explanatory factor of the price of gasoline (Federal Trade Commission, 2005). When the world price of crude oil rises, U.S. refiners must pay higher prices for it. Facing this higher input cost from crude, refiners then charge more for the gasoline they sell at wholesale which forces gas stations to charge consumers more at the pump, since they also face higher input costs.

In 1973-1974, the U.S. faced the so-called "Energy Crisis" due to the Arab oil embargo and a quadrupling of world crude oil prices by OPEC. This crisis caused dramatic social, political, and economic changes, and led the U.S. to use a "Price Control" policy in the domestic energy market. Under these price control policies, the U.S. set different oil prices to insulate the U.S. economy and market participants from the dramatic increase in foreign oil prices.

A large literature has looked at the welfare losses of price controls in energy markets. Agarwal and Deacon (1985) looked at the petroleum industry price and allocation controls in the U.S. during the I970's, and they found that regulations consistently kept price below marginal cost, causing the overall volume of refined product output to be excessive and this led to inefficient distribution of the product to consumers. Camm (1983) discussed the impacts of the price control policy on gasoline customers. He shows that customers were paying higher prices than the regulated prices due to the long time wait and cost of wasted time. Frech and Lee (1987) showed how to ration a good across markets (rationing-by-queuing.), while doing the least harm to consumer welfare. They provide empirical estimates from U. S. gasoline crises of 1973-1974 and 1979 of the extra welfare losses caused by misallocation of gasoline between urban and rural markets. Smith and Phelps (1978) looked at the impact of price controls on U.S. domestic oil production. They showed that price controls during 1974-76 have generated a perverse supply curve such that future increases in real world oil prices will transfer proportionately more U. S. income to OPEC than past price increases. Kalt (1981) showed that price controls have an ambiguous effect on total domestic output. This is due to the fact that price controls can either raise or lower the value of current rents relative to the value of future rents, causing the time path of extraction from existing reserves to be ambiguous. Also price 
controls reduce the absolute present value of the streams of rents going to producers, resulting in reduction in exploration and development of new reserves. Kalt found that price controls caused a deadweight loss to the U.S. economy ranging from $\$ 1-5$ billion yearly.

On the whole, the effects of price controls on crude oil producers and refiners in the U.S. have been explored and well documented (Kalt, 1981). However, the responses of OPEC producers to such a policy need further attention. This paper tests empirically the effect of the U.S. price control policies on OPEC's decisions, and explores if OPEC's behavior was affected by these policies, particularly the oil extraction decisions of OPEC. This paper is organized as follows: Section II gives a brief description of the history of oil price control policies in the U.S. Section III examines the effects of these price controls on OPEC. Section IV reports the findings of the relation between the harm function and the change in OPEC's production, and finally, Section V concludes.

\section{THE HISTORY OF OIL PRICE CONTROL POLICIES IN THE U.S. 1971-1988 (1)}

As summarized by Kalt (1981), there is an academic consensus regarding price controls and regulations imposed on refined products and crude oil, and their significant negative effects on oil producers and consumers alike. In this section I document the history of the US oil price controls.

\section{II.1 Oil Price Controls: 1971-1973}

In 1970, President Nixon utilized the broad powers given to him by the congress to launch America's grand experiment with price controls, which then gave way to the Economic Stabilization Act of 1970. The President's price control regime consisted of four phases.

Phase I of the experiment applied to wages and prices throughout the economy, and lasted from August to November 1971. Due to the stabilized nature of oil prices during this period, Phase I had minimal effect on oil markets.

Phase II of the experiment was more liberal in nature and lasted from November 1971 to January 1973. Under this phase all firms excluding the oil and gas sectors were allowed to increase prices above the designated price ceiling of Phase I of the experiment, in order to reflect the increase in production cost.

During Phase II the gasoline, heating oil, residual fuel and crude oil prices were locked at Phase I levels. This inflexibility resulted in heating oil shortages during the winter of 1972-1973. However, due to soft global prices, the other industry products remained unaffected by the price control.

Phase III of the experiment lasted from January 1973 to August 1973. During this Phase conforming to the Phase II price control became voluntary. However, extenuating circumstances such as increased heating oil prices and political pressure compelled the Nixon Administration to issue "Special Rule No. 1, in March 1973. The Special Rule reinstated strict price controls on the 23 largest domestic oil companies that accounted for about 95 percent of the industry's gross sales. However, the smaller oil companies were not subject to such price control. The lack of controls on the smaller firms' prices resulted in a failure to control market-clearing prices. In the spring of 1973 the market-clearing prices were rising amid the increase in world prices and dollar devaluation.

Phase III price controls and Special Rule No. 1 affected the market in significant ways, due to the fact that 23 large oil companies were the major suppliers to the independent gasoline stations at the time. The strict price controls imposed on the big companies and the provisions in Phase III which prevented the aforementioned companies from recovering the rising price of crude imports, if they were refined into products, resulted in a reduction of the large companies' crude imports and their sale of refined products to others. Consequently, the independent marketers, distributors, and bulk consumers faced shortages in acquiring fuel for their customers. Such shortages in the market created political demands for sharing the shortages equally. These pressures resulted in a set of Phase IV price controls for the petroleum industry. In November of 1973, the Phase IV price control regulations were placed in the Emergency Petroleum Allocation Act (EPAA). 


\section{II.2 The Emergency Petroleum Allocation Act (EPAA) of 1973}

The EPAA was adopted to address the independent gas stations' displeasure about being cut off from the major oil companies' product supplies as a result of restrictions imposed on the latter by Special Rule No. 1 and Phase III. As such, the EPPA placed a halt on buyer-seller relations that existed in 1972, and required a federal approval for major changes in buyer-seller relationships, involving regulators in the daily operations of the industry.

Furthermore, the EPAA endorsed a two-tier system of price control on domestic oil. Under the two-tier system, the oil that was discovered previously was dubbed as "old oil" and was subject to strict price control (2). On the other hand "new oil" was not subject to price control (3). In addition, the oil wells that produced less than 10 barrels of oil per day became exempt from the price control regime in November 1973.

The EPAA produced an allocation problem. The problem occurred because there was no price control on imported crude necessary to meet the domestic demand; however, domestic old oil was subject to strict price control. Therefore, the cost of imported oil was a determining factor in the marginal cost for gasoline sold in the United States. As such, the refiners that had access to old oil profited much more from gasoline sales than those refiners who relied on imported crude.

To remedy this allocation problem, the Federal Energy Administration (FEA) espoused an "old oil entitlement" for individual refineries on a month to month basis. The purpose of entitlements was to equate each refinery's access to "old oil" to the national average in refinery access to "old oil". As such, those refineries that made use of old oil in their operations more than the national average access to old oil were forced to buy entitlements from those refineries that used less old oil than the national average.

An old oil entitlement program resulted in an increase in crude imports. The reason for the increase was because, by importing more crude, the refineries were able to reduce their dependence on "old oil" and were subsequently entitled to receive subsidies from other refineries. The incentive to increase imports continued until the value of entitlement tickets equaled the value of the rents created by the price controls (the difference between the world price for oil and controlled prices times the volume of old oil).

Although, the purpose of the entitlements program was to balance and make equal the profits across refineries, later interventions ultimately favored and benefited some refineries over others. The "Small Refiner Bias" regulation, which gave small refineries extra entitlements to old oil, was an example of preferential treatment for some refineries at the expense of others. There were also various other exemptions and responses to appeals given by regulators as "hardship relief" under the FEA.

\section{II.3 The Energy Policy \& Conservation Act of 1975}

The Energy Policy and Conservation Act (EPCA) was an amendment to the EPAA which took effect in February 1976. EPCA expanded price controls to cover the "new oil" products from domestic fields that came about after the creation of EPAA. As a result, a new three-tier price control system emerged and replaced the previous two-tier control system. The new system introduced a binding average price for domestic oil of $\$ 7.66$ per barrel. This figure was then allowed to be increased up to 10 percent annually to account for various incentive payments and inflation (4). The EPCA was amended in September 1976. The new amendment allowed the average domestic prices to rise 10 percent annually regardless of the inflation rate and regulatory incentives adjustments. In addition, the EPCA removed price controls for major refined oil products except for propane, jet fuel, and gasoline.

The new three-tier regulatory system involved changes in the entitlements program for "old oil". Changes were required because the "old oil" was now segmented into two categories of lower tier "old oil" which was less expensive, and the upper-tier "old oil" which was more expensive. As such, each barrel of upper-tier oil was given a portion of the entitlement granted to lower tier oil.

The old oil entitlement program continued its granting of special exemptions. In April 1976, the residual imports to the East Coast became eligible for partial entitlements. In addition, in February and March of 1977 middle distillates were given partial entitlements as a response to the severe winter of that year. 
Fortunately, the EPCA gave the President the authority to halt the petroleum price controls after May 1979. As a result the Carter administration made energetic use of this authority and decontrolled the jet fuel prices immediately thereafter. In addition, in June 1979, the Administration removed price controls from oil properties not producing in 1978, in addition to the offshore properties leased after December 1978. Furthermore, 80 percent of the production from the marginal lower-tier properties was decontrolled in June 1979.

Subsequently, the producers were allowed to redefine how much oil would be allocated between lower and higher tier categories (5). As such, the heavy crude oil was decontrolled on August 17, 1979. In addition, in January 1980, 4.6 percent of a property's upper-tier outputs were decontrolled each month. Then to offset the expenses associated with newly-undertaken tertiary recovery projects, smaller amounts of lower tier oil were decontrolled.

In summary, President Carter dismantled the price control system to a large extent through administrative action. President Ronald Reagan, in turn, abolished all remaining controls in January 1981 as his first official acts as President. The EPCA formally expired in September 1981, as the Congress did not make an effort to reauthorize the program.

\section{II.4 The Windfall Profit Tax: 1980-1988}

To replace the EPAA/EPCA, the Crude Oil Windfall Profit Tax (WPT) was enacted in April 1980. The name of this tax was a bit misleading, as this was not a tax on profits, but rather an excise tax on domestic oil production, effective March 1, 1980. These taxes were paid before the oil sales profits were determined. As such, profits had no effect on how much windfall profit tax was paid. However, producers were able to deduct the aforementioned taxes from income tax liabilities as it was considered a cost of doing business.

The excise taxes were enforced based on the difference between the market price for oil and a set "base price" which was adjusted quarterly to account for inflation and state severance taxes. The taxes were generally applied at the point of first sale to a refiner. The rates were:

- $\quad$ Tier One oil, which included most domestic oil in reservoirs that were productive before 1979 got 70 percent. In addition, the law established a base price for Tier One oil equal to the upper-tier base price established under the EPCA on May 1979, adjusted for inflation.

- $\quad$ The stripper oil and oil from the Naval Petroleum Reserve, received 60 percent. The Law designated a base price for Tier Two oil equal to the Tier One price plus $\$ 1$. The stripper oil was completely exempted from the tax.

- $\quad$ Tier Three oil, which included output from the posts that were newly producing post-1978 properties, heavy crude oil, and incremental oil from tertiary recovery, received 30 percent. The law designated a base price for Tier Three oil equal to the upper-tier ceiling under the EPCA on May 1979, plus \$2. However, the tax on newly discovered oil was reduced gradually, to 22.5 percent.

- The independent producers who made sales less than $\$ 1.25$ million quarterly or with less than 50,000 barrels of production per day were taxed on the first 1000 barrels of oil per day. Moreover, they paid reduced taxes on that oil; 50 percent for Tier One oil and 30 percent for Tier Two oil. Such independents only paid 30 percent on Tier Three oil with an exemption for the first 1,000 barrels per day.

- $\quad$ The oil produced by state or local governments, educational or charitable medical institutions, Indian tribes or individual Indians over which the U.S exercised trust responsibilities, oil produced in much of Alaska and the first increments of tertiary oil all received tax exemptions.

Finally, the Windfall Profit Tax was scheduled to expire over 33 months, after January 1988, or the first month after the revenues from the tax have equaled \$227.3 billion, but no later than January 1991.

\section{THE EFFECTS OF THE U.S. PRICE CONTROLS ON OPEC}

The major issue in this section is to examine how OPEC responded to the price controls adopted by the U.S. In other words, did OPEC cut production during the time periods in which the U.S. adopted the price control policies, or these policies had no effect at all on OPEC's oil extraction decisions? 
OPEC's oil production and reserves are the levels reported by OPEC in its Annual Statistical Bulletin for different years (1989-2007). OPEC's Annual Statistical Bulletin provides data about world energy markets. It contains statistical data regarding the oil and gas activities of OPEC's member countries (Algeria, Angola, Ecuador, Indonesia, Iran, Iraq, Kuwait, Libya, Nigeria, Qatar, Saudi Arabia, the United Arab Emirates and Venezuela), as well as the global petroleum industry in general. It also provides comprehensive and detailed data on upstream and downstream activities, and the global flows of oil and gas, in addition to basic financial data about some of the world's largest oil and gas companies. Crude oil production and exports for OPEC Members from 1970 - 2007 are in $1,000 \mathrm{~b}$ /day.

To explore the response of OPEC to the U.S. price controls, we start by detrending the secular production levels of OPEC. This is done by regressing OPEC's production levels from 1960 to 2007 on a time index, ranging from linear up to a sixth order polynomial. Then, by calculating the Schwarz Information Criteria (SIC), the best detrending model will be identified as the one with the minimum SIC (8). Using this criterion, the secular production trend was best captured by a sixth order polynomial trend.

The residuals from this trend capture the effects of the unobservable factors on production levels such as cost, expectations and more, including the response of OPEC to the price control policies. Now, one can argue that these residuals may be used to show and test the impact of the price control policies on OPEC's production. The residuals from this trend are displayed in Figure 1. The plotted residuals show some evidence that the production levels were lower in years 1975, 1976, 1979, 1981-1986, and 1988, when compared to years before and after. This is how one can attribute the negative deviations from the secular trend for these years. Now, do these reductions in OPEC production reflect responses to the price controls or not? To test what we observe from the plotted residuals, a relationship between these residuals and the price control periods should be estimated. This means we need to regress these residuals on the price control periods. To be able to do so, one needs to include five dummy variables for these periods, where each equals one if it is the year or years in which the specific price control was applied, and zero otherwise (e.g. for the period 1970, D1 = 1 for this year, and zero otherwise. For the period 1971-1972, D2 = 1 for this period, and zero otherwise).

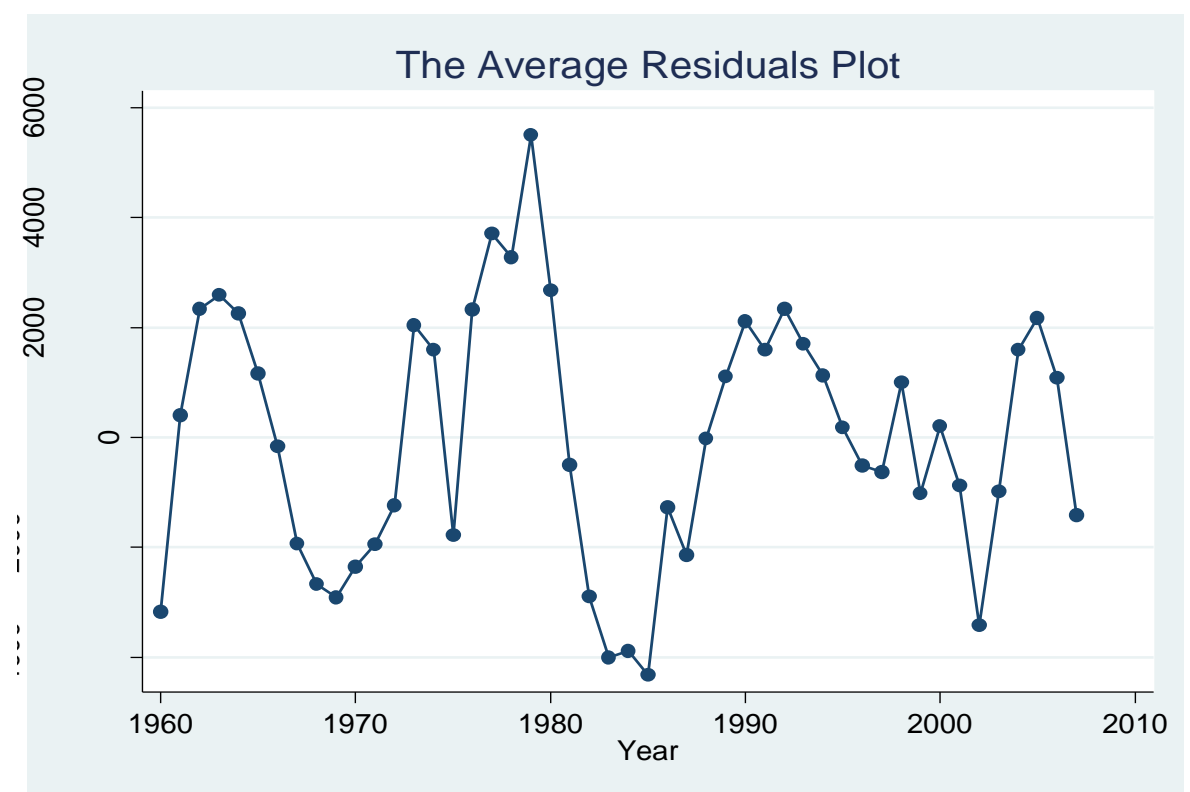

Figure 1: Average Residuals Plot

Following these notions, our model regresses the residuals, plotted in Figure 1, on five dummies matching the periods when price controls were applied, and OPEC's reserves in year $(t)$, with a constant. 
$\operatorname{Resid}_{t}=\alpha_{0}+\alpha_{1} R_{t}+\alpha_{2} D_{2}+\alpha_{3} D_{3}+\alpha_{4} D_{4}+\alpha_{5} D_{5}+\alpha_{6} D_{6}$

where, $\operatorname{Resid}_{t}$ is the residuals from the regression of the production levels from 1960 to 2007 on a time index, $R_{t}$ is OPEC's reserves in year ( $t$ ), $D_{1}$ is a dummy variable for the period 1970 (the base and is dropped), $D_{2}$ is a dummy variable for the period 1971-1972, $\mathrm{D}_{3}$ is a dummy variable for the period $1973, \mathrm{D}_{4}$ is a dummy variable for the period 1974-1975, $D_{5}$ is a dummy variable for the period 1976-1979, and $D_{6}$ is a dummy variable for the period 1980-1988. The results are reported in Table 1.

Table 1: Regression of Residuals on OPEC Reserves and Price Control Dummies

\begin{tabular}{|c|c|c|c|}
\hline Variable & Coefficient & Robust Std. Err. & t - values \\
\hline OPEC's reserves & 0.0007 & 0.001 & 0.49 \\
\hline Dummy for $1971-1972$ & $-1539.34 * * *$ & 600.76 & -2.56 \\
\hline Dummy for 1973 & $2097.37 * * *$ & 582.46 & 3.97 \\
\hline Dummy for $1974-1975$ & -85.21 & 1371.69 & -0.06 \\
\hline Dummy for $1976-1979$ & $3736.75^{* * *}$ & 804.84 & 4.64 \\
\hline Dummy for $1980-1988$ & $-1856.53 * *$ & 865.51 & -2.15 \\
\hline Constant & -343.42 & 1066.62 & -0.32 \\
\hline R-squared & 0.39 & & \\
\hline Number of observations & 48 & & \\
\hline \multicolumn{4}{|c|}{$\begin{array}{l}\text {-The dependent variable is the residuals of regressing the production levels from } 1960 \text { to } 2007 \text { on a time index. The table reports } \\
\text { the coefficients of the regression of these residuals on the five dummies and OPEC's reserves, with a constant. } \\
\text { - Year } 1970 \text { is the base. } \\
\text {-Robust standard errors and t-values are reported in the table. } \\
\text { *** Significant at the } 1 \% \text { level. } \\
\text { ** Significant at the } 5 \% \text { level. }\end{array}$} \\
\hline
\end{tabular}

In Table 1, the difference between the coefficients of any two consecutive dummies can be interpreted as the difference between the levels of production, on average. The reported coefficients show some evidence that the production levels of OPEC were affected by the price controls policies for some periods.

For the period 1971-1972, the average loss in production amounts to approximately 1196 (1000 barrel/day) with respect to the previous period in which price controls were used, and 3637 (1000 barrel/day) with respect to the following period, and both differences are statistically significant (different from zero).

For 1973, OPEC increased production, according to the estimated coefficients. The average increase in production amounts to approximately 3637 (1000 barrel/day) with respect to the previous period, and to 2183 (1000 barrel/day) with respect to the following period, and both differences are statistically significant (different from zero). This result seems odd, given that 1973 is the year in which Arab members of OPEC banned exports to western countries and the U.S. due to the 1973 war. One explanation for this could be that the war did not occur until October of that year. So perhaps these countries, in earlier parts of 1973, were planning for the war and increasing oil output to support such activities. This might have led them to expand extraction at the beginning of 1973, and perhaps that's what the coefficient is capturing.

This argument can be supported by the estimates on the 1974-1975 periods, when production is lower than in the previous or following time periods. The Arab members of OPEC were perhaps still using the ban, and were also responding to the U.S. price control policies. The average loss in production amounts to approximately 2183 
(1000 barrel/day) with respect to the previous period, and to 3822 (1000 barrel/day) with respect to the following period. Both differences are statistically significant (different from zero). OPEC's production levels increased for 1976-1979, and were not affected by the U.S. price control policies. This indicates that OPEC members were trying to recover their foregone revenues to address growth needs inside their countries. Finally, the estimated coefficients show some evidence that OPEC responded by cutting production when the U.S. implemented the "Windfall Profit Tax", from 1980-1988. OPEC cut production by 5593 (1000 barrel/day) on average, and this difference is statistically significant. This result is supported by the work of Karp and Newbery (1991), where they found that OPEC will initially have a lower share of current production than of current reserves when the U.S. and other large importers all impose optimal import tariffs. However, through this period (1980-1988), oil prices were decreasing (see Figure 2 in the appendix) and these cuts could have been made by OPEC to help prices increase, rather than the decline is a response to the Windfall Profit Tax.

This section shows some evidence that OPEC did respond differently to price controls applied by the U.S. For some periods it cut production, while in other periods production levels increased. Although, these increases or decreases are not related only to the price control policies, it still explains some of the variation in production levels.

\section{RELATION BETWEEN HARM FUNCTION AND RESIDUALS}

OPEC includes Algeria, Indonesia, Iran, Iraq, Kuwait, Libya, Nigeria, Qatar, Saudi Arabia, United Arab Emirates, and Venezuela. Following the approach suggested by Wirl (2008), these countries can be divided into allies and adversaries, in terms of their relations with the West. Countries like Indonesia, Kuwait, Nigeria, Qatar, Saudi Arabia, and United Arab Emirates are seen as allies to the European countries and the U.S. Countries like Iran, Algeria and Venezuela are considered to be anti-West (until 2003, Iraq and Libya considered to be in this group). Following Wirl (2008), the hypothesis in this paper is that OPEC countries do not pursue strict profit maximization. Indeed, they also seek political support among their people. These countries realize that the Wes depends on OPEC's oil; this gives them some power of influence. The people of these countries frequently express anti-Western sentiments (9). For this reason, OPEC countries in need of popular domestic support may take production decisions to gain such support. The statements and interviews that we read and watch for Ahmadi Nejad of Iran and Chavez of Venezuela are good examples of these policies. Even countries considered to be allies must still secure the support of their people, some of whom also have anti-Western sentiments. Such countries (allies) may adopt a moderate anti-Western policy. With the political consideration in mind, OPEC countries will be assumed to maximize the net present value of benefits, where benefits are derived from oil profits as well as political support, based on the degree to which the west is harmed.

Following Wirl (2008), let the political support among citizens of the country be $\mathrm{S}_{\mathrm{t}}$. Political support is a function of the adverse effect on the West of higher oil prices, so $S_{t}$ is the harm function (10). This harm function depends on the quantity of oil extracted and supplied to the market, and on an indicator, $\alpha_{t}$, that measures the desire of OPEC to harm the West.

The harm function can be written as: $S_{t}=f\left(q_{t}, \alpha_{t}\right)$

OPEC is able to harm the western countries and the U.S. by cutting production and raising the price. Recall that OPEC has direct control over quantity not price, as the latter is determined in the market.

The political support $\left(\mathrm{S}_{\mathrm{t}}\right)$ will increase as $\left(\mathrm{q}_{\mathrm{t}}\right)$ is cut or if the desire to harm $\left(\alpha_{\mathrm{t}}\right)$ is stronger. This means:

$\partial \mathrm{S}_{\mathrm{t}} / \partial \mathrm{q}_{\mathrm{t}}<0$

$\partial \mathrm{S}_{\mathrm{t}} / \partial \alpha_{\mathrm{t}}>0$

Using these notions, a simple form of the harm function with appropriate properties is:

$\mathrm{S}_{\mathrm{t}}=\alpha_{\mathrm{t}} /\left(1+\mathrm{q}_{\mathrm{t}}\right)$ 
Equation (5) implies that the harm decreases when OPEC increases quantities (one in the denominator avoids the case of infinity when quantity is zero). Also the harm increases with a higher desire to harm, $\alpha_{t}$. If OPEC has no desire to harm anyone, then $\alpha_{t}=$ zero and the harm function vanishes, meaning that OPEC just maximizes profits like any other producer in any market with no other considerations in mind.

Since one of the factors that might affect the secular trend for OPEC's production levels is this desire to harm the west, we can obtain an estimate of $\alpha_{t}$ by estimating the relationship:

$\operatorname{Resid}_{\mathrm{t}}=\alpha_{0}+\alpha_{1}\left\{1 /\left(1+\mathrm{q}_{\mathrm{t}}\right)\right\}$

and taking the estimate of $\alpha_{1}$ as a measure of $\alpha_{t}$. This relationship also explores the relation between the residuals and the harm function. The idea is that the harm function might have affected OPEC's decisions regarding oil extraction. If this is the case, then one should expect to find a relation between these residuals and the harm function. The estimates of the regression are reported in Table 2.

Table 2: Regression of Residuals on Harm Function

\begin{tabular}{|c|c|c|c|}
\hline Variable & Coefficient & Robust Std. Err. & t - values \\
\hline $1 /\left(1+q_{t}\right)$ & $-2.37 \mathrm{e}+07$ & $1.78 \mathrm{e}+07$ & -1.33 \\
\hline Constant & 1146.75 & 863.31 & 1.33 \\
\hline R-squared & 0.04 & & \\
\hline Number of observations & 48 & & \\
\hline
\end{tabular}

The results show that the coefficient for the harm function is negative and a large number, although it is not significant. This is consistent with the results found in Kisswani (2009), where the net present value of profits increases with a large value of the harm indicator, $\alpha_{t}$. The regression outcome here also provides some evidence that OPEC considers the harm function when it comes to oil extraction. This part provides some evidence that OPEC members did consider the support of their citizens in deciding on production levels, and this support, which is represented by the harm function, needed OPEC to cut production as a response to the U.S. price controls.

\section{CONCLUSIONS}

The arguents in this paper provide some evidence that OPEC did respond to the price controls applied by the U.S., but not in a uniform way. For some periods it cut production, while in other periods production levels increased. Since this is the case, the U.S. may consider different policies to address high oil prices, especially since price control policies also have adverse effects on welfare. Also the analysis gives some support to the idea that OPEC members consider the support of their citizens when deciding on production levels. However, most of those citizens are to be Anti-Western. Therefore, the U.S. and the West should review their policy in the region to improve relations with OPEC's governments. Beside they need to communicate better with the people of OPEC countries, since they are the main drivers of the harm function that results in restrictions on oil output and higher market prices.

\section{AUTHOR INFORMATION}

Khalid M. Kisswani, Ph.D. Before joining Gulf University for Science \& Technology, Dr. Kisswani has held academic appointments at Quinnipiac University, Eastern Connecticut State University, University of Hartford, University of Nevada, and College of Southern Nevada, USA. Dr. Kisswani was listed on the "National Dean's List" 2004-2005, The Honor society of Phi Kappa Phi-2005, the "Chancellor's List" 2006, and on "Who's Who among Executives and Professionals, Honors Edition" 2008-2009. Dr. Kisswani's work has been published in 
several conference proceedings and refereed journals, such as Journal of Economics \& Finance, the Journal of Business and Economic Perspectives, the Empirical Economics Letters, and Economics Bulletin. E-mail: kisswani.k@gust.edu.kw

\section{Endnotes}

1. This section draws upon Kalt (1981), Taylor and Van Doren (2006).

2. The means by which the law defined "old oil" was quite complicated. Output from a domestic property in each month of 1972 was defined at that property's base period control level (BPCL) for that month. If a property had once produced more than its BPCL, the amount by which production in any subsequent month fell short of the BPCL was added into a property's current cumulative deficiency (CCD). Output in any month less than or equal to the sum of the BPCL and the CCD was defined as "old oil."

3. Output greater than the sum of a property's BPCL and CCD, or from properties not producing in 1972, was defined as "new oil." Each barrel of "new" domestic oil brought to market allowed a producer to release a barrel from its "old oil" classification.

4. Under the Energy Policy \& Conservation Act, the BPCL for a property in any month was defined as the lesser of the average monthly output of "old oil" in 1975 and the average monthly output of all oil in 1972. "Lower-Tier" oil was defined as output not in excess of that property's BPCL plus CCD. "Upper-Tier" oil was defined as production from pre-1976 properties in excess of the associated lower-tier output and production from properties that began producing after 1975. Lower-Tier oil sold at its May 15, 1973 price plus inflation and incentive adjustment factors determined by the U.S. Department of Energy. Upper-Tier oil sold at its September 30, 1975 price less \$1.32 plus inflation and incentive adjustment factors. Alaskan North Slope crude oil was treated as upper-tier crude for regulatory purposes. Crude from the Federal Naval Petroleum Reserves and incremental production from tertiary oil recovery projects was not controlled. The oil release program (established as part of the EPAA) under which increases in production above base period 1972 levels would not only be free of price controls but also remove an equivalent amount of old oil from controls was repealed.

5. Producers were allowed to redefine the BPCLs of lower-tier properties to the average output in the six months ending March 1979 and to establish CCDs at zero. Thereafter, BPCLs were reduced by 1.5 percent a month in 1979 and 3 percent per month between 1980 and October 1981.

6. Primary production methods utilize natural gas or water pressure. Secondary recovery methods inject water or natural gas into wells to force the oil to the surface. Tertiary methods recover oil by reducing its viscosity (resistance to flow) through heating (usually steam injection) and sometimes the use of soap to dissolve the crude in water.

7. The WPT was a legislative compromise between the Carter Administration, which supported decontrol of oil prices, and congressmen who feared that decontrol would lead to steep price increases. Many analysts had long argued, however, that a windfall profit tax was a much more efficient and less economically destructive means of transferring wealth from major oil producers to politically favored beneficiaries.

8. The Schwarz Information Criterion (SIC) has been widely used for model identification in time series and linear regression. SIC is an index used as an aid in choosing between competing models. It was proposed as a method for choosing between different models with different numbers of parameters, in order to determine which is the "best fit" to the observed data.

9. They disagree primarily with the American and European policy toward the Arab-Israeli conflict.

10. Citizens of the Middle East and some Latin Americans believe that the US policy is targeting them, and that it ignores the good aspects of their countries. This is why most of them consider themselves to be "Anti West".

\section{REFERENCES}

1. Agarwal, V. B., Deacon, R. T., (1985). Price Controls, Price Dispersion and the Supply of Refined Petroleum Products. Journal of Energy Economics. 7(4), 210-219

2. Camm, F., (1983). Market Behavior under Partial Price Controls: the Case of the Retail Gasoline Market. Rand Corp. No. R-2613-DOE/RC.

3. Federal Trade Commission, (2005). Gasoline Price Changes: The Dynamic of Supply, Demand, and Competition. 
4. $\quad$ Frech III, H. E. , Lee, W. C. , (1987). The Welfare Cost of Rationing-By-Queuing across Markets: Theory and Estimates from the U. S. Gasoline Crises. The Quarterly Journal of Economics. 102 (1), 97 108.

5. Kalt, J. P., (1981). The Economics and Politics of Oil Price Regulation. MIT Press. Cambridge, MA.

6. Karp, L., Newbery, D., (1991). OPEC and the U.S. Oil Import Tariff. The Economic Journal. 101(405), 303-313.

7. Kisswani, K., (2009). Economics of Oil Prices and the Role of OPEC, University of Connecticut, Working paper.

8. Smith, R. T., Phelps, C. E., (1978). The Subtle Impact of Price Controls on Domestic Oil Production. The American Economic Review. 68(2), 428-433.

9. Taylor, J., Van Doren, P., (2006). The Case against the Strategic Petroleum Reserve. Policy Analysis. No. 561, January 12. Cato Institute. Washington D.C.

10. Wirl, F., (2008). Why Do Oil Prices Jump (or Fall). Energy Policy. 36 (3), 1029-1043. 


\section{APPENDIX}

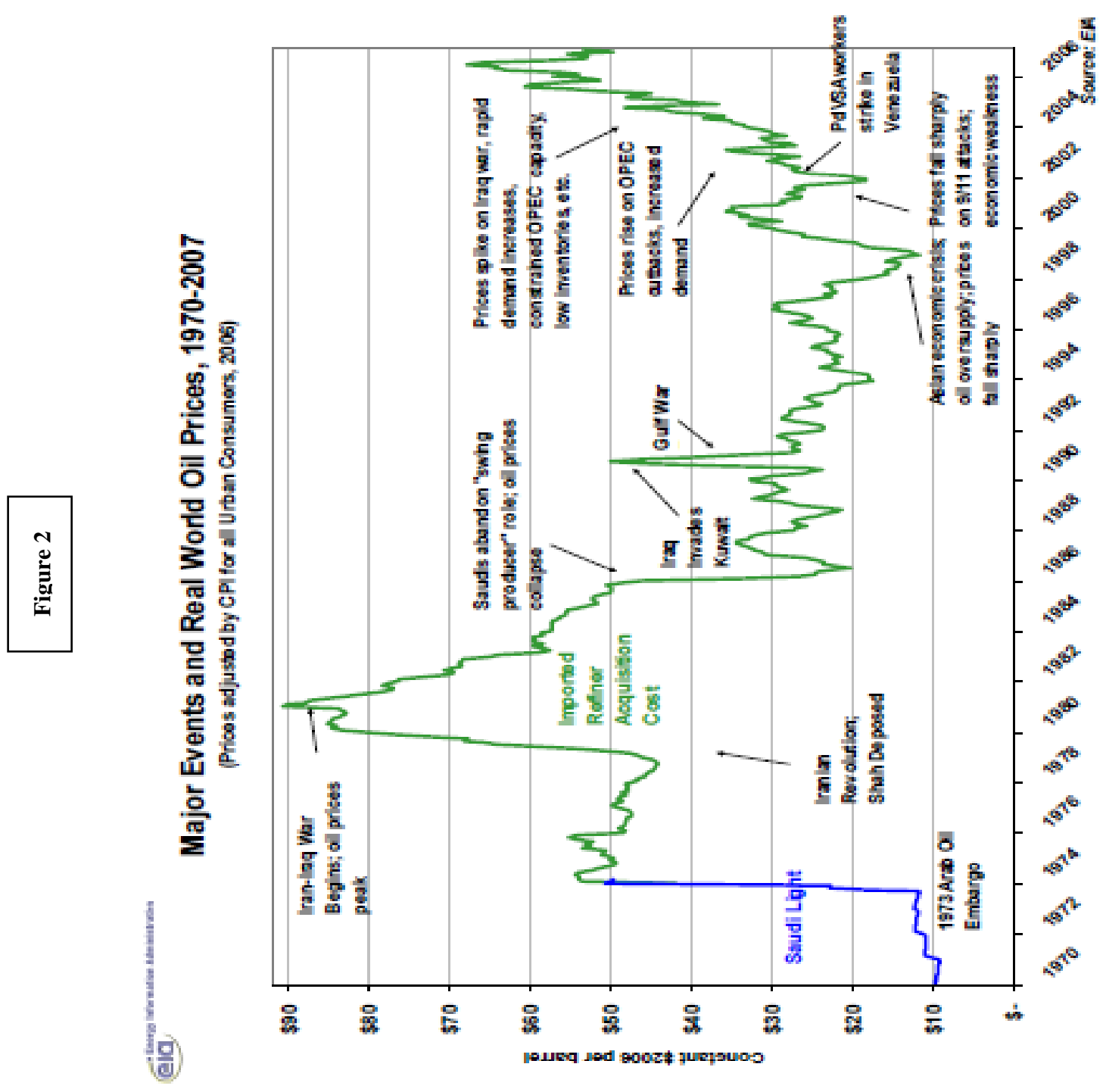




\section{NOTES}

